\title{
Pertanggungjawaban Pejabat Pemerintahan Sebagai Akibat Penyalahgunaan Wewenang Yang Menimbulkan Kerugian Negara
}

\author{
Henny Juliani \\ Fakultas Hukum Universitas Diponegoro \\ Jl. Prof. Soedarto, SH Tembalang Semarang \\ Email: hennyjuliani.fhundip@gmail.com.
}

\begin{abstract}
This research is aimed to find out legal basis of Government Officer responsibility as consequence of authority abused that cause state financial lost. This research used normative juridical method by using analytical descritive approach. This research found out that Government Officers (including treasurers, non treasurer public servants, or other officers), could be penalized to fine if there is mal-administration in their decission or actions that cause state financial lost. The fine will become personal responisbility if there is abuse of power. Otherwise, state financial lost will be compesate to government institutions as official responsibilitynif there is not any abuse of power. Government officers who defined to compensate government financial lost can be penalized with administrative penalty and/or criminal penalty. Criminal penalty will not release compensation obligation.
\end{abstract}

Keyword: responsibility, abuse of power, public finance

\begin{abstract}
Abstrak
Penelitian ini bertujuan untuk mengetahui pertanggungjawaban Pejabat Pemerintahan sebagai akibat penyalahgunaan wewenang yang menimbulkan kerugian keuangan negara berdasarkan peraturan perundang-undangan. Metoda penelitian yang digunakan adalah yuridis normatif dengan spesifikasi penelitian deskriptif analitis. Dari hasil penelitian dapat diketahui bahwa Pejabat Pemerintahan (termasuk di dalamnya bendahara, pegawai negeri bukan bendahara, atau pejabat lain), dapat dikenai tuntutan ganti kerugian negara/daerah jika Keputusan dan/atau Tindakan yang ditetapkan dan/atau dilakukan terdapat kesalahan administratif yang menimbulkan kerugian keuangan negara. Pengembalian kerugian negara dibebankan kepada Pejabat Pemerintahan sebagai tanggung jawab pribadi apabila ada unsur penyalahgunaan wewenang. Sedangkan pengembalian kerugian negara dibebankan kepada Badan Pemerintahan sebagai tanggung jawab jabatan apabila terjadi bukan karena adanya unsur penyalahgunaan wewenang. Oleh karena itu Pejabat Pemerintahan yang telah ditetapkan untuk mengganti kerugian negara/daerah dapat dikenai sanksi administratif dan/atau sanksi pidana. Putusan pidana tidak membebaskan dari tuntutan ganti rugi.
\end{abstract}

Kata kunci: pertanggungjawaban, penyalahgunaan wewenang, keuangan negara 


\section{A. Pendahuluan}

Presiden Republik Indonesia memegang kekuasaan pemerintahan menurut Undang-Undang Dasar. Hal tersebut ditegaskan dalam Pasal 4 ayat (1) Undang-Undang Dasar Negara Republik Indonesia Tahun 1945 (UUD 45), sebagai pedoman untuk mencapai tujuan negara dalam menyejahterakan rakyat . Presiden selaku Kepala Pemerintahan memegang kekuasaanpengelolaan keuangan negara sebagai bagian dari kekuasaan pemerintahan yang meliputi kewenangan yang bersifat umum dan kewenangan yang bersifat khusus. Di sini Presiden berkedudukan sebagai Chief Executive Officer (CEO).

Penyelenggaraan pemerintahan negara tersebut menimbulkan hak dan kewajiban negara yang dapat dinilai dengan uang. Hak dan kewajiban negara tersebut perlu dikelola dalam sistem pengelolaan keuangan negara secara profesional, terbuka, dan bertanggungjawab agar kemakmuran rakyat dapat terwujud melalui Anggaran Pendapatan dan Belanja Negara (APBN) maupun Anggaran Pendapatan dan Belanja Daerah (APBD).

Menurut Pasal 6 ayat (2) Undang-Undang Nomor 17 Tahun 2003 tentang Keuangan Negara, kekuasaan atas pengelolaan keuangan negara yang dimiliki Presiden tersebut selanjutnya dikuasakan kepada Menteri Keuangan selaku pengelola fiskal dan Wakil Pemerintah dalam kepemilikan kekayaan negara yang dipisahkan. Dikuasakan juga kepada Menteri/Pimpinan Lembaga selaku Pengguna Anggaran/Pengguna Barang kementerian negara/lembaga yang dipimpinnya. Kekuasaan Presiden tersebut juga diserahkan kepada Gubernur/Bupati/Walikota selaku kepala pemerintahan daerah untuk mengelola keuangan daerah dan mewakili pemerintah daerah dalam kepemilikan kekayaan daerah yang dipisahkan. Oleh karena itu dalam Penjelasan Umum UndangUndang Nomor 17 Tahun 2003 dinyatakan bahwa Menteri Keuangan sebagai pembantu Presiden dalam bidang keuangan pada hakikatnya adalah Chief Financial Officer (CFO) Pemerintah Republik Indonesia, sedangkan setiap menteri/pimpinan lembaga pada hakikatnya adalah Chief Operational Officer (COO) untuk suatu bidang tertentu pemerintahan. Prinsip tersebut memberikan kejelasan dalam pembagian wewenang dan tanggung jawab, terlaksananya mekanisme check and balances serta mendorong upaya peningkatan profesionalisme dalam penyelenggaraan tugas pemerintahan. 
Berdasarkan Pasal 6 ayat (1) Undang-Undang Nomor 30 Tahun 2014 tentang Administrasi Pemerintahan dinyatakan bahwa Pejabat Pemerintahan memiliki hak untuk menggunakan kewenangan dalam mengambil Keputusan dan/atau Tindakan. Di sisi lain sebagaimana diatur dalam Pasal 7 ayat (1), Pejabat Pemerintahan berkewajiban untuk menyelenggarakan administrasi pemerintahan sesuai dengan ketentuan peraturan perundang-undangan, kebijakan pemerintahan, dan AUPB. Dalam menjalankan kewenangan pemerintahan tersebut, Pejabat Administrasi Pemerintahan dilarang menyalahgunakan kewenangan dalam menetapkan dan/atau melakukan Keputusan dan/atau Tindakan. Hal tersebut ditegaskan dalam Pasal 8 ayat (3).

Ketentuan peraturan perundang-undangan telah mengatur kewenangan Pejabat Pemerintahan dalam menjalankan fungsi pengelolaan keuangan negara beserta hak dan kewajibannya serta larangan penyalahgunaan kewenangan dalam menjalankan fungsinya tersebut, namun apabila penyalahgunaan kewenangan yang menimbulkan kerugian keuangan negara tetap terjadi maka perlu diketahui sampai sejauh mana Pejabat Pemerintahan tersebut harus mempertanggungjawabkannya. Oleh karena itu dilakukan penelitian dengan judul: "Pertanggungjawaban Pejabat Pemerintahan sebagai Akibat Penyalahgunaan Wewenang yang Menimbulkan Kerugian Negara.”

Penelitian ini akan dikaji dari sudut pandang hukum dengan menggunakan pendekatan yuridis normatif, karena masalah yang akan diteliti berhubungan erat dengan law in books, yaitu penelitian yang dilakukan dari data sekunder. Menurut Ronny Hanitijo Soemitro, data sekunder di bidang hukum (dipandang dari sudut kekuatan mengikatnya), dapat dibedakan menjadi bahan-bahan hukum primer, bahanbahan hukum sekunder, dan bahan hukum tersier ${ }^{1}$. Berbagai ketentuan peraturan perundang-undangan yang menjadi dasar kajian penelitian ini akan dijadikan bahan utama dalam mengungkapkan permasalahan yang diteliti. Oleh karena itu maka spesifikasi penelitian yang digunakan adalah deskriptif analitis, yang selanjutnya bahanbahan tersebut akan dianalisis secara kualitatif.

\section{Konsep Pengelolaan Keuangan Negara}

1 Ronny Hanityo Soemitro, 1994, Metodologi Penelitian Hukum dan Yurimetri, Jakarta, Ghalia lndonesia, hlm 11-12 
Pasal 6 ayat (1) Undang-Undang Nomor 17 Tahun 2003 tentang Keuangan Negara yang menyatakan bahwa Presiden selaku Kepala Pemerintahan memegang kekuasaan pengelolaan keuangan negara sebagai bagian dari kekuasaan pemerintahan. Kekuasaan tersebut selanjutnya dikuasakan kepada Menteri Keuangan, dikuasakan juga kepada Menteri/ Pimpinan Lembaga. Kekuasaan tersebut juga diserahkan kepada Gubernur/Bupati/Walikota. Hal tersebut diatur dalam Pasal 6 ayat (2) Undang-Undang Nomor 17 Tahun 2003 tentang Keuangan Negara. Ketentuan lebih lanjut tentang pengelolaan dan pertanggungjawaban keuangan negara diatur dalam Undang-Undang Nomor 1 Tahun 2004 tentang Perbendaharaan Negara.

Konsekuensi pembagian tugas antara Menteri Keuangan dengan para menteri lainnya dapat dilihat dari proses pelaksanaan anggaran dimana dilakukan pemisahan secara tegas antara pemegang kewenangan administratif dengan pemegang kewenangan kebendaharaan. Penyelenggaraan kewenangan administratif yang diserahkan kepada kementerian negara/lembaga meliputi kewenangan melakukan perikatan atau tindakantindakan lainnya yang mengakibatkan terjadinya penerimaan atau pengeluaran negara, melakukan pengujian dan pembebanan tagihan yang diajukan kepada kementerian negara/lembaga sehubungan dengan realisasi perikatan tersebut, serta memerintahkan pembayaran atau menagih penerimaan yang timbul sebagai akibat pelaksanaan anggaran. Di sisi yang lain penyelenggaraan kewenangan kebendaharaan diserahkan kepada Kementerian Keuangan. Menteri Keuangan merupakan Bendahara Umum Negara, dan pejabat lainnya yang ditunjuk sebagai Kuasa Bendahara Umum Negara bukanlah sekedar kasir yang hanya berwenang melaksanakan penerimaan dan pengeluaran negara tanpa berhak menilai kebenaran penerimaan dan pengeluaran tersebut. Menteri Keuangan selaku Bendahara Umum Negara merupakan pengelola keuangan dalam arti seutuhnya, yaitu berfungsi secara sekaligus sebagai kasir, pengawas keuangan, dan manajer keuangan. Hal tersebut ditegaskan dalam Penjelasan Umum Undang-Undang Nomor 1 Tahun 2004 tentang Perbendaharaan Negara.

Fungsi pengawasan keuangan yang dilakukan oleh Menteri Keuangan tersebut terbatas pada aspek rechtmatigheid dan wetmatigheid saja dan hanya dilakukan pada saat terjadinya penerimaan atau pengeluaran, sehingga berbeda dengan fungsi pre-audit yang dilakukan oleh kementerian teknis atau post-audit yang dilakukan oleh aparat pengawasan fungsional. 
Berdasarkan pemisahan yang tegas antara pemegang kewenangan administratif (ordonnateur) dengan pemegang kewenangan kebendaharaan (comptable), maka akan dapat dijalankan salah satu prinsip pengendalian intern yang berperan penting dalam proses pelaksanaan anggaran. Hal tersebut dimaksudkan untuk mencegah dan/atau meminimalkan terjadinya penyimpangan dalam pelaksanaan penerimaan dan pengeluaran negara, apabila pemisahan tersebut dilakukan secara konsisten.

Penyelenggaraan pemerintahan negara, baik pada tataran pemerintah pusat maupun pemerintah daerah dalam rangka mewujudkan tujuan bernegara harus menimbulkan hak dan kewajiban negara yang perlu dikelola dan dipertanggungjawabkan dalam suatu sistem pengelolaan dan pertanggungjawaban keuangan negara. Sebab, pengaturan dalam sistem hukum keuangan negara yang baik dan wajar merupakan suatu conditione sine qua non dalam rangka pelaksanaan dan pertumbuhan pembangunan. Karena salah satu perwujudan dari tata kelola yang baik itu pelaksanaan pembangunan yang tepat sasaran dan memberikan dampak nyata bagi kesejahteraan masyarakat. Hal inilah yang sesuangguhnya menjadi impian dan cita-cita sebuah negara kesejahteraan (welfare state), khususnya Indonesia. ${ }^{2}$

Indonesia menganut konsep negara hukum baru yang lebih dinamis yakni yang dikenal dengan istilah welfare state (negara kesejahteraan) atau negara hukum materiil. Di dalam welfare state pemerintah itu diserahi bestuurzorg yaitu penyelenggaraan kesejahteraan umum.3Berkaitan dengan konsep negara kesejahteraan yang merupakan revisi dari konsep negara pasif, Asshiddiqie sebagaimana dikutip oleh W Riawan Tjandra menguraikan bahwa dalam konsep negara kesejahteraan ini, negara dituntut untuk memperluas tanggung jawabnya kepada masalah-masalah sosial ekonomi yang dihadapi rakyat banyak. ${ }^{4}$

\section{Konsep Wewenang dan Penyalahgunaan Wewenang}

Menurut Philipus M Hadjon, istilah wewenang digunakan dalam bentuk kata benda. Istilah itu seringkali dipertukarkan dengan istilah kewenangan. Istilah wewenang

2 Beni Kurnia Illahi dan Muhammad Ikhsan Alia, Pertanggungjawaban Pengelolaan Keuangan Negara Melalui Kerjasama BPK dan KPK, p-ISSN: 2477-118X Volume 3 Nomor 2-Desember 2017

3 SF Marbun dan Moh. Mahfud MD, 1987, Pokok-pokok Hukum Administrasi Negara, Yogyakarta, Liberty, hlm 45

4 W Riawan Tjandra, 2008, Hukum Administrasi Negara, Yogyakarta, Penerbit Universitas Atma Jaya, hlm 9. 
atau kewenangan sering disejajarkan dengan istilah "bevoegdheid" dalam istilah hukum Belanda. Menurutnya, ada sedikit perbedaan antara istilah wewenang atau kewenangan dengan istilah bevoegdheid. Perbedaan terletak dalam karakter hukumnya. Istilah Belanda bevoegdheid digunakan baik dalam konsep hukum publik maupun hukum privat. Dalam hukum kita, istilah kewenangan atau wewenang seharusnya digunakan selalu dalam konsep hukum publik.

Menurut F.A.M. Stroink sebagaimana dikutip Hadjon, dalam konsep hukum publik, wewenang merupakan suatu konsep inti dalam hukum tata negara dan hukum administrasi. Hadjon juga mengutip pendapat Henc van Maarseveen, bahwa dalam konsep hukum publik, wewenang berkaitan dengan kekuasaan hukum, yang sekurangkurangnya terdiri dari tiga komponen, yaitu: komponen pengaruh, komponen dasar hukum, dan komponen konformitas hukum. Komponen pengaruh ialah bahwa penggunaan wewenang dimaksudkan untuk mengendalikan perilaku subyek hukum. Komponen dasar hukum, bahwa wewenang itu selalu harus dapat ditunjuk dasar hukumnya, dan komponen komformitas hukum mengandung makna nadanya standar wewenang, yaitu standar umum (semua jenis wewenang) dan standar khusus (untuk jenis wewenang tertentu $)^{5}$.

Wewenang merupakan kekuasaan (hak) yang diberikan kepada pejabat publik atau pemerintah untuk memerintah atau bertindak. Dalam menjalankan kewenangan itu ada kewajiban bagi pejabat publik untuk mematuhi aturan hukum. Sebab seperti dikemukakan oleh Artidjo Alkostar bahwa timbulnya korupsi tidak terlepas dari kekuasaan yang tidak terkontrol atau penyalahgunaan kekuasaan. Karena itu ada batasan-batasan yang patut dipatuhi oleh pemegang wewenang itu. ${ }^{6}$

Penyalahgunaan wewenang dalam konsep HAN selalu diparalelkan dengan konsep detournement de pouvoir, dalam arti pengunaan wewenang tidak sebagaimana mestinya. Dalam hal ini pejabat menggunakan wewenangnya untuk tujuan lain yang menyimpang dari tujuan yang telah diberikan kepada wewenang itu. Dengan demikian

5 Philipus M Hadjon. dkk 2011, Hukum Administrasi dan Tindak Pidana Korupsi, Yogyakarta: Gadjah Mada University Press, hlm 10-11

6 Marojahan JS Panjaitan, Penyelesaian Penyalahgunaan wewenang yang Menimbulkan Kerugian Negara Menurut Hukum Administrasi Pemerintahan, Jurnal Hukum Ius Quia Iustum, volume 24, Issue 3, Juli 2017, hlm 437 
pejabat melanggar asas spesialitas. Ada tidaknya unsur penyalahgunaan wewenang diuji dengan asas spesialitas, yakni asas yang menentukan bahwa wewenang itu diberikan kepada organ pemerintahan dengan tujuan tertentu. Dalam mengukur apakah telah terjadi penyalahgunaan wewenang, haruslah dibuktikan bahwa pejabat telah menggunakan wewenangnya untuk tujuan lain.

Terjadinya penyalahgunaan wewenang bukanlah karena suatu kealpaan. Penyalahgunaan wewenang dilakukan secara sadar yaitu mengalihkan tujuan yang telah diberikan kepada wewenang itu. Pengalihan tujuan didasarkan atas interest pribadi yang negatif, baik untuk kepentingan dirinya sendiri ataupun untuk orang lain. Ada tidaknya pengalihan tujuan harus dibuktikan. Sepanjang tidak ada bukti menyangkut pengalihan tujuan berarti tidak ada penyalahgunaan wewenang. ${ }^{7}$

Larangan penyalahgunaan wewenang dalam Undang-Undang Nomor 30 Tahun 2014 tentang Administrasi Pemerintahan termuat dalam Pasal 17 ayat (1) dan (2), yaitu bahwa: Badan dan/atau pejabat pemerintahan dilarang menyalahgunakan wewenang, meliputi: a. Larangan melampaui wewenang; b. Larangan mencampuradukkan wewenang; dan/atau c.Larangan bertindak sewenang-wenang.

Selanjutnya Pasal 18 Undang-Undang Nomor 30 Tahun 2014 menyatakan bahwa: Badan dan/atau pejabat pemerintahan dikategorikan melampaui wewenang apabila keputusan dan/atau tindakan yang dilakukan: a. Melampaui masa jabatan atau batas waktu berlakunya wewenang; $b$. Melampaui batas wilayah berlakunya wewenang; dan/atau c. Bertentangan dengan ketentuan peraturan perundangundangan. Badan dan/atau Pejabat Pemerintahan dikategorikan mencampuradukkan wewenang apabila keputusan dan/atau tindakan yang dilakukan: a. Di luar cakupan bidang atau materi wewenang yang diberikan; dan/atau b. Bertentangan dengan tujuan wewenang yang diberikan. Badan dan/atau Pejabat Pemerintahan dikategorikan bertindak sewenang-wenang, apabila keputusan dan/atau tindakan yang dilakukan: a. Tanpa dasar kewenangan; dan/atau b.Bertentangan dengan Putusan Pengadilan yang berkekuatan hukum tetap.

$7 \quad$ Op cit. hlm 21-22 
Menurut Krishna Djaya Darumurti telah terjadi kekeliruan dalam mengartikan penyalahgunaan wewenang sebagaimana diatur dalam Undang-Undang Nomor 30 Tahun 2014. Penyalahgunaan wewenang (detournement de pouvoir) berbeda dengan bertindak sewenang-wenang (willekeur). Ada tidaknya unsur penyalahgunaan wewenang diuji dengan Asas-asas Umum Pemerintahan yang Baik yakni asas yang menentukan bahwa wewenang itu diberikan kepada organ pemerintahan dengan tujuan tertentu. Jika menyimpang dari tujuan diberikannya wewenang ini dianggap sebagai penyalahgunaan wewenang. Unsur sewenang-wenang diuji dengan asas rasionalitas atau kepantasan (redelijk). Suatu kebijakan dikategorikan mengandung unsur willekeur jika kebijakan itu nyata-nyata tidak masuk akal atau tidak beralasan (konnelijk onredelijk). ${ }^{8}$

\section{c. Terminologi Kerugian Keuangan Negara}

Pasal 35 Undang-Undang Nomor 17 Tahun 2003 mengintepretasikan atau menganalogikan "kerugian keuangan negara" sama dengan "kerugian negara", sebagaimana berikut ini:

(1) Setiap pejabat negara dan pegawai negeri bukan bendahara yang melanggar hukum atau melalaikan kewajibannya baik langsung atau tidak langsung yang merugikan keuangan negara diwajibkan mengganti kerugian dimaksud.

(2) Setiap orang yang diberi tugas menerima, menyimpan, membayar, dan/atau menyerahkan uang atau surat berharga atau barang-barang negara adalah bendahara yang wajib menyampaikan laporan pertanggungjawaban kepada Badan Pemeriksa Keuangan.

(3) Setiap bendahara sebagaimana dimaksud dalam ayat (2) bertanggung jawab secara pribadi atas kerugian keuangan negara yang berada dalam pengurusannya.

(4) Ketentuan mengenai penyelesaian kerugian negara diatur di dalam undangundang mengenai perbendaharaan negara.

Selanjutnya terminologi "kerugian negara" yang digunakan berdasarkan rumusan Undang-undang Nomor 1 Tahun 2004 tentang Perbendaharaan Negara Pasal 1 angka 22 adalah bahwa: "kerugian negara/daerah adalah kekurangan uang, surat berharga, dan barang, yang nyata dan pasti jumlahnya sebagai akibat perbuatan melawan hukum baik sengaja maupun lalai." Dalam Penjelasan Umum angka 6 tentang Penyelesaian Kerugian Negara, ditegaskan bahwa setiap kerugian

8 Krishna Djaya Darumurti, Op Cit, hlm. 133 
negara/daerah yang disebabkan oleh tindakan melawan hukum atau kelalaian seseorang harus diganti oleh pihak yang bersalah. Dengan penyelesaian kerugian tersebut negara/daerah dapat dipulihkan dari kerugian yang telah terjadi.

Pasal 59 Undang-Undang Nomor 1 Tahun 2004 tentang Perbendaharaan Negara mengatur tentang Penyelesaian Kerugian Negara/Daerah yang disebabkan oleh tindakan melanggar hukum atau karena kelalaian harus segera diselesaikan sesuai dengan peraturan perundang-undangan yang berlaku. Dalam hal tindakan tersebut dilakukan oleh Bendahara, Pegawai Negeri bukan bendahara, atau pejabat lain secara langsung merugikan keuangan negara, maka wajib mengganti kerugian tersebut. Setiap pimpinan kementerian negara/lembaga/kepala satuan kerja perangkat daerah dapat segera melakukan tuntutan ganti rugi setelah mengetahui terjadinya kerugian akibat perbuatan pihak manapun.

Dalam Hukum Administrasi Negara, rumusan merugikan keuangan negara diinterpretasikan sama dengan kerugian negara. Hal tersebut dapat dilihat pada ketentuan Pasal 35 ayat (1) dan ayat (4) Undang-Undang Nomor 17 Tahun 2003 tentang Keuangan Negara; Pasal 1 angka 22, dan Pasal 59 sampai dengan Pasal 67 Undang-undang Nomor 1 Tahun 2004 tentang Perbendaharaan Negara. Ditegaskan lagi dalam Pasal 64 ayat (2) bahwa putusan pidana tidak membebaskan dari tuntutan ganti rugi. ${ }^{9}$

\section{B. Hasil dan Pembahasan}

\section{Pertanggungjawaban Pejabat Pemerintahan dalam Penyalahgunaan}

\section{Wewenang}

Willekeur/unreasonableness (sewenang-wenang) atau detournement de pouvoir/abuse of power (penyalahgunaan wewenang) menjadi kompetensi pengadilan (PTUN) untuk menilainya, berdasarkan Pasal 21 Undang-Undang Nomor 30 Tahun 2014: (1) Pengadilan berwenang menerima, memeriksa, dan memutuskan ada atau tidak ada unsur penyalahgunaan wewenang yang dilakukan oleh pejabat pemerintahan. (2) Badan dan/atau pejabat pemerintahan dapat

$9 \quad$ Henny Juliani, Penyelesaian Tuntutan Ganti Kerugian Negara/Daerah terhadap Pegawai Negeri Bukan Bendahara dan Pejabat Lain, https://ejournal.undip.ac.id/index.php/lawreform/ article/view/16158 
mengajukan permohonan kepada pengadilan untuk menilai ada atau tidak ada unsur penyalahgunaan wewenang dalam keputusan dan/atau tindakan.

Ketentuan Pasal 21 Undang-Undang Nomor 30 Tahun 2014 tentang Administrasi Pemerintahan dilaksanakan dengan Peraturan MA Nomor 4 Tahun 2015 tentang Tata cara Penilaian Unsur Penyalahgunaan Wewenang. PTUN berwenang menilai setelah diperoleh hasil pengawasan yang dilakukan oleh aparat pengawasan intern pemerintah.

Hasil pengawasan aparat pengawasan intern pemerintah berupa: a. Tidak terdapat kesalahan; b. Terdapat kesalahan administratif;c. Terdapat kesalahan administratif yang menimbulkan kerugian keuangan negara. Jika terdapat kesalahan administratif, maka dilakukan tindak lanjut dalam bentuk penyempurnan administrasi sesuai ketentuan peraturan perundang-undangan. Jika terdapat kesalahan administratif yang menimbulkan kerugian keuangan negara, dilakukan pengembalian kerugian keuangan negara paling lama 10 (sepuluh) hari kerja terhitung sejak diputuskan dan diterbitkannya hasil pengawasan. Pengembalian kerugian negara dibebankan kepada badan pemerintahan, apabila kesalahan administratif terjadi bukan karena adanya unsur penyalahgunaan wewenang. Pengembalian kerugian negara dibebankan kepada pejabat pemerintahan, apabila kesalahan administratif terjadi karena adanya unsur penyalahgunaan wewenang.

Akibat hukum penyalahgunaan wewenang diatur dalam Pasal 19 UndangUndang Nomor 30 Tahun 2014 yaitu terhadap keputusan dan/atau tindakan yang ditetapkan dan/atau dilakukan dengan melampaui wewenang atau secara sewenangwenang menjadi tidak sah apabila telah diuji dan ada putusan pengadilan yang berkekuatan hukum tetap. Keputusan dan/atau tindakan yang ditetapkan dan/atau dilakukan dengan mencampuradukkan wewenang dapat dibatalkan apabila telah diuji dan ada putusan pengadilan yang berkekuatan hukum tetap.

Menurut Supandi penyalahgunaan wewenang mempunyai karakter atau ciri: ${ }^{10} 1$. Menyimpang dari tujuan atau maksud dari suatu pemberian kewenangan; 2. Menyimpang dari tujuan atau maksud dalam kaitannya dengan asas legalitas; 
3.Menyimpang dari tujuan atau maksud dalam kaitannya dengan asas-asas umum pemerintahan yang baik. Penyalahgunaan wewenang menurut Pasal 3 UndangUndang Pemberantasan Tindak Pidana Korupsi (UU Nomor 31 Tahun. 1999 yang diubah dengan Undang-Undang Nomor 20 Tahun 2021) adalah: "Setiap orang yang dengan tujuan menguntungkan diri sendiri atau orang lain atau suatu korporasi, menyalahgunakan kewenangan, kesempatan atau sarana yang ada padanya karena jabatan atau kedudukan yang dapat merugikan keuangan negara atau perekonomian negara, dipidana dengan pidana penjara seumur hidup atau pidana penjara.....dst"

Unsur menyalahgunakan kewenangan dalam Pasal 3 UU PTPK memiliki pengertian yang berbeda dengan penyalahgunaan kewenangan dalam Pasal 21 ayat (1) UU Administrasi Pemerintahan.Terdapat kesulitan dalam membedakan kapan seorang aparatur negara itu melakukan perbuatan melawan hukum yang masuk dalam ruang lingkup hukum pidana dan kapan dapat dikatakan melakukan penyalahgunaan wewenang yang masuk dalam ruang lingkup hukum administrasi negara? Menurut Supandi secara substansial, asas spesialitas mengandung makna bahwa setiap kewenangan memiliki tujuan tertentu. Penyimpangan terhadap asas ini akan melahirkan penyalahgunaan wewenang. Parameter peraturan perundangundangan maupun asas-asas umum pemerintahan yang baik dipergunakan untuk membuktikan instrumen atau modus penyalahgunaan kewenangan (Pasal 3 UU PTPK). Sedangkan penyalahgunaan kewenangan baru dapat diklasifikasikan sebagai tindak pidana apabila berimplikasi terhadap kerugian negara atau perekonomian negara (kecuali untuk tindak pidana korupsi suap, gratifikasi, dan pemerasan), tersangka mendapat keuntungan, masyarakat tidak dilayani, dan perbuatan tersebut merupakan tindak tercela.

Konsep penyalahgunaan wewenang merupakan konsep yang berlaku dalam HAN, untuk itu penyelesaiannya harus berlaku dan melalui prosedur HAN sebagaimana asas hukum yang berlaku dalam HAN bahwa badan/pejabat TUN dilindungi berdasarkan asas prae sumptio iustae causa, dimana keputusan yang diambil oleh badan/pejabat TUN harus dianggap benar sebelum adanya putusan pengadilan yang berkekuatan hukum tetap. Selain itu juga untuk mempertahankan prinsip ultimum remedium terhadap penegakan hukum pidana, sehingga tidak semua 
kebijakan dapat dipidana sebelum diupayakan menurut kaidah-kaidah hukum yang berlaku dalam HAN. ${ }^{11}$

Perbandingan antara Tanggung Jawab Jabatan dan Tanggung Jawab Pribadi digambarkan oleh Philipus M Hadjon dalam bagan berikut:

\begin{tabular}{|c|c|}
\hline Tanggung Jawab Jabatan & Tanggung Jawab Pribadi \\
\hline $\begin{array}{l}\text { Fokus : legalitas(keabsahan) tindakan } \\
\text {-Wewenang } \\
\text {-Prosedur } \\
\text {-Substansi }\end{array}$ & $\begin{array}{l}\text { Fokus : maladministrasi } \\
\text { Perilaku jelek aparat dalam } \\
\text { pelaksanaan tugas } \rightarrow \text { perbuatan tercela } \\
\text { Antara lain : } \\
\text {-sewenang-wenang } \\
\text {-Penyalahgunaan wewenang }\end{array}$ \\
\hline $\begin{array}{l}\text { Parameter: } \\
\text {-Peraturan perundang-undangan } \\
\text {-Asas-asas umum pemerintahan yang } \\
\text { baik }\end{array}$ & $\begin{array}{l}\text { Parameter: } \\
\text { 1. Peraturan perundangan } \\
\text { 2. Asas-asas umum pemerintahan } \\
\text { yang baik } \\
\text { 3. Code of good administrative } \\
\text { behavior (Uni Eropa) }\end{array}$ \\
\hline $\begin{array}{l}\text { Pertanyaan hukum: } \\
\text { Adakah cacat yuridis menyangkut: } \\
\text {-Wewenang } \\
\text {-Prosedur } \\
\text {-substansi }\end{array}$ & $\begin{array}{l}\text { Pertanyaan hukum: } \\
\text { Adakah maladministrasi } \\
\text { tindakan tersebut? }\end{array}$ \\
\hline $\begin{array}{l}\text { Asas praesumptio iustae causa } \\
\text { (praduga sah) } \\
\text { Setiap tindakan pemerintah harus } \\
\text { dianggap sah sampai ada pencabutan } \\
\text { atau pembatalan }\end{array}$ & $\begin{array}{l}\text { Berkaitan dengan tindak pidana: asas } \\
\text { praduga tak bersalah }\end{array}$ \\
\hline Asas vicarious liability: berlaku & Asas vicarious liability: tidak berlaku \\
\hline Sanksi: administrasi, perdata & Sanksi: administrasi, perdata, pidana \\
\hline
\end{tabular}

2. Tuntutan Ganti Kerugian Negara/Daerah terhadap Bendahara, Pegawai Negeri Bukan Bendahara atau Pejabat Lain

Terhadap bendahara, maka Pasal 35 ayat (3) Undang-Undang Nomor 17 Tahun 2003 menyatakan bahwa: "Setiap bendahara bertanggungjawab secara pribadi

$11 \quad$ Ibid, hlm. 432 
atas kerugian keuangan negara yang berada dalam pengurusannya." Pasal 62 ayat (1) Undang-Undang Nomor 1 Tahun 2004 menyatakan bahwa: "Pengenaan ganti kerugian negara/daerah terhadap bendahara ditetapkan oleh Badan Pemeriksa Keuangan." Selanjutnya dalam ayat (2) dinyatakan bahwa: “Apabila dalam pemeriksaan kerugian negara/daerah ditemukan unsur pidana, BPK menindaklanjutinya sesuai dengan peraturan perundang-undangan yang berlaku." Ketentuan lebih lanjut tentang pengenaan ganti rugi diatur dalam Undang-Undang mengenai pemeriksaan pengelolaan dan tanggung jawab keuangan negara (ayat 3), yaitu Undang-Undang Nomor 15 Tahun 2004.

Ditegaskan lagi dalam Pasal 64 Undang-Undang Nomor 1 Tahun 2004, bahwa bendahara, pegawai negeri bukan bendahara, dan pejabat lain yang telah ditetapkan untuk mengganti kerugian negara/daerah dapat dikenai sanksi administratif dan/atau sanksi pidana (ayat 1). Putusan pidana tidak membebaskan dari tuntutan ganti rugi (ayat 2).

Untuk melaksanakan ketentuan Pasal 63 ayat (2) Undang-Undang Nomor 1 Tahun 2004 tentang Perbendaharaan Negara, maka ditetapkan Peraturan Pemerintah Nomor 38 Tahun 2016 tentang Tata Cara Tuntutan Ganti Kerugian Negara/Daerah terhadap Pegawai Negeri Bukan Bendahara atau Pejabat Lain.

Dalam Peraturan Pemerintah ini, yang dimaksud dengan Tuntutan Ganti Kerugian menurut Pasal 1 angka 2 adalah suatu proses tuntutan yang dilakukan terhadap pegawai negeri bukan bendahara atau pejabat lain dengan tujuan untuk memulihkan Kerugian Negara/Daerah. Selanjutnya menurut angka 3, Pegawai Negeri Bukan Bendahara adalah Pegawai Aparatur Sipil Negara, Anggota Tentara Nasional Indonesia, Anggota Kepolisian Negara Republik Indonesia yang bekerja/diserahi tugas selain tugas bendahara. Sedangkan yang dimaksud dengan Pejabat Lain menurut angka 4 adalah pejabat negara dan pejabat penyelenggara pemerintahan yang tidak berstatus pejabat negara, tidak termasuk bendahara dan Pegawai Negeri Bukan Bendahara. Selanjutnya menurut angka 5, yang dimaksud dengan. Pihak Yang Merugikan adalah Pegawai Negeri Bukan Bendahara atau Pejabat Lain yang berdasarkan hasil pemeriksaan menimbulkan Kerugian Negara/Daerah. 
Pasal 2 ayat (1) Peraturan Pemerintah ini mengatur tata cara Tuntutan Ganti Kerugian Negara/Daerah atas uang, surat berharga, dan/atau barang milik negara/daerah yang ruang lingkupnya berada dalam penguasaan: a. Pegawai Negeri Bukan Bendahara; atau b. Pejabat Lain: 1) pejabat negara; dan 2) pejabat penyelenggara pemerintahan yang tidak berstatus pejabat negara, tidak termasuk bendahara dan Pegawai Negeri Bukan Bendahara. Yang dimaksud dengan pejabat negara adalah pejabat negara sebagaimana dimaksud dalam Undang-Undang Nomor 5 Tahun 2014 tentang Aparatur Sipil Negara, sebagaimana diatur dalam Pasal 122.

Pejabat penyelenggara pemerintahan yang tidak berstatus pejabat negara adalah ketua dan anggota DPRD sebagai pejabat daerah serta pimpinan dan anggota lembaga non struktural yang dibiayai APBN/APBD. Pasal 3 ayat (1) Peraturan Pemerintah ini menyatakan bahwa: Setiap Pegawai Negeri Bukan Bendahara atau Pejabat Lain wajib melakukan tindakan pengamanan terhadap:

a. uang, surat berharga, dan/atau barang milik negara/daerah yang berada dalam penguasaannya dari kemungkinan terjadinya Kerugian Negara/Daerah; dan/atau b. uang dan/atau barang bukan milik negara/daerah yang berada dalam penguasaannya dari kemungkinan terjadinya Kerugian Negara/Daerah.

Selanjutnya ayat (2) menyatakan bahwa Setiap Pegawai Negeri Bukan Bendahara atau Pejabat Lain yang melanggar hukum atau melalaikan kewajibannya baik langsung atau tidak langsung yang merugikan keuangan negara/daerah diwajibkan mengganti kerugian dimaksud.

Berdasarkan laporan hasil verifikasi sebagaimana dimaksud dalam Pasal 5 ayat (3), Pejabat Penyelesaian Kerugian Negara/Daerah (PPKN/D) harus menyelesaikan Kerugian Negara/Daerah dengan melaksanakan Tuntutan Ganti Kerugian. PPKN/D sebagaimana dimaksud dalam Pasal 7 adalah sebagai berikut:

a. Menteri/Pimpinan Lembaga, dalam hal kerugian negara dilakukan oleh Pegawai Negeri Bukan Bendahara atau Pejabat Lain di lingkungan Kementerian Negara/Lembaga;

b. Menteri Keuangan selaku Bendahara Umum Negara, dalam hal kerugian negara dilakukan oleh Menteri/Pimpinan Lembaga; 
c. Gubernur, Bupati, atau Walikota, dalam hal kerugian daerah dilakukan oleh Pegawai Negeri Bukan Bendahara atau Pejabat Lain di lingkungan Pemerintahan Daerah; atau

d. Presiden, dalam hal Kerugian Negara/Daerah dilakukan oleh Menteri Keuangan selaku Bendahara Umum Negara/Pimpinan Lembaga Negara/Gubernur, Bupati, atau Walikota.

Kewenangan PPKN/D untuk menyelesaikan Kerugian Negara/Daerah dilaksanakan oleh:

a. Kepala satuan kerja untuk kerugian negara yang dilakukan oleh Pegawai Negeri Bukan Bendahara atau Pejabat Lain di lingkungan Kementerian Negara/Lembaga; dan

b. Kepala Satuan Kerja Pengelola Keuangan Daerah selaku Bendahara Umum Daerah untuk kerugian daerah yang dilakukan oleh Pegawai Negeri Bukan Bendahara atau Pejabat Lain di lingkungan Pemerintahan Daerah.

Pasal 17 ayat (1) menyatakan bahwa Penggantian Kerugian Negara/Daerah segera dibayarkan secara tunai atau angsuran. Ayat (2) selanjutnya mengatur dalam hal Kerugian Negara/Daerah sebagai akibat perbuatan melanggar hukum, Pihak Yang Merugikan/Pengampu/Yang Memperoleh Hak/Ahli Waris wajib mengganti Kerugian Negara/Daerah paling lama 90 (sembilan puluh) hari kalender sejak SKTJM ditandatangani.

Oleh karena itu maka terhadap bendahara, pegawai negeri bukan bendahara, dan pejabat lain yang melakukan tindakan melanggar hukum sehingga menimbulkan kerugian keuangan negara harus bertanggung jawab secara pribadi dan kepadanya dapat dikenai sanksi administratif dan/atau sanksi pidana. Pertanggungjawaban pejabat pemerintahan berupa pengembalian kerugian negara juga diatur dalam Pasal 20 ayat (6) Undang-Undang Nomor 30 Tahun 2014 yaitu apabila kesalahan administratif yang menimbulkan kerugian keuangan negara tersebut terjadi karena adanya unsur penyalahgunaan wewenang. Dengan demikian yang terjadi adalah tanggung jawab pribadi, namun berdasarkan Pasal 20 ayat (5), pengembalian kerugian keuangan negara akan dibebankan kepada Badan Pemerintahan, apabila kesalahan administratif yang menimbulkan kerugian keuangan negara terjadi bukan 
karena adanya unsur penyalahgunaan wewenang, dengan demikian yang terjadi adalah tanggung jawab jabatan.

Dari sudut pandang hukum pidana, Hernold Ferry Makawimbang menyatakan bahwa delik "merugikan keuangan negara" dalam Pasal 2 dan 3 Undang-Undang Nomor 31 Tahun 1999 merupakan unsur paling dominan dalam pembuktian tindak pidana korupsi. Setiap adanya unsur "merugikan keuangan negara"memberikan kontribusi besar pada terpenuhinya unsur tindak pidana korupsi, karena ada "perbuatan sengaja merugikan"dengan cara melawan hukum (strafbaar feit atau criminal act) dan adanya akibat terjadi "kerugian keuangan negara"(natuur feit atau een positief element) yang akhirnya memperkaya diri sendiri, orang lain atau corporate yang bukan haknya tetapi "hak keuangan" oleh negara. ${ }^{12}$

\section{Simpulan}

Berdasarkan penelitian yang telah dilakukan, maka dapat disimpulkan bahwa pertanggungjawaban Pejabat Pemerintahan (termasuk di dalamnya bendahara, pegawai negeri bukan bendahara, atau pejabat lain) sebagai akibat penyalahgunaan wewenang yang menimbulkan kerugian negara, dapat dikenai tuntutan ganti kerugian negara/daerah apabila tindakan/perbuatannya dilakukan secara melanggar hukum atau karena kelalaian yang secara langsung menimbulkan kerugian keuangan negara/daerah, sehingga wajib mengganti kerugian tersebut untuk memulihkan kerugian negara/daerah.

Pengembalian kerugian negara dibebankan kepada Pejabat Pemerintahan sebagai tanggung jawab pribadi apabila kesalahan administratif yang menimbulkan kerugian keuangan negara terjadi karena adanya unsur penyalahgunaan wewenang. Sedangkan pengembalian kerugian negara dibebankan kepada Badan Pemerintahan sebagai tanggung jawab jabatan, apabila kesalahan administratif yang menimbulkan kerugian keuangan negara tersebut terjadi bukan karena adanya unsur penyalahgunaan wewenang. Pejabat Pemerintahan yang telah ditetapkan untuk mengganti kerugian negara/daerah dapat dikenai sanksi administratif dan/atau sanksi pidana. Putusan pidana tidak menghapuskan dari tuntutan ganti rugi.

12 Hernold Ferry Makawimbang, 2014, Kerugian Keuangan Negara, Yogyakarta, Thafa Media, hlm. 18 


\section{Daftar Pustaka}

Beni Kurnia Illahi dan Muhammad Ikhsan Alia, Pertanggungjawaban Pengelolaan Keuangan Negara Melalui Kerjasama BPK dan KPK, p-ISSN: 2477-118X Volume 3 Nomor 2-Desember 2017

Darumurti, Krishna Djaya 2016, Diskresi Kajian Teori Hukum, (Yogyakarta: Genta Publishing);

Hadjon, Philipus M. dkk 2011, Hukum Administrasi dan Tindak Pidana Korupsi, (Yogyakarta: Gadjah Mada University Press);

Henny Juliani, Penyelesaian Tuntutan Ganti Kerugian Negara/Daerah terhadap Pegawai Negeri Bukan Bendahara dan Pejabat Lain, https://ejournal.undip.ac.id/index.php/lawreform/ article/view/16158

HR, Ridwan, 2013, Hukum Administrasi Negara Edisi Revisi, (Jakarta: Raja Grafindo Persada);

Makawimbang, Hernold Ferry, 2014, Kerugian Keuangan Negara, (Yogyakarta: Thafa Media);

Marbun, SF dan Moh. Mahfud MD, 1987, Pokok-pokok Hukum Administrasi Negara,( Yogyakarta: Liberty);

Marojahan JS Panjaitan, Penyelesaian Penyalahgunaan wewenang yang Menimbulkan Kerugian Negara Menurut Hukum Administrasi Pemerintahan, Jurnal Hukum Ius Quia Iustum, volume 24, Issue 3, Juli 2017, hlm 437

Soemitro, Ronny Hanitijo, 1994, Metodologi Penelitian Hukum dan Yurimetri, (Jakarta: Ghalia lndonesia);

Supandi, 2019, Hukum Peradilan Tata Usaha Negara, Bandung: Alumni, hlm. 431

Tjandra, W Riawan, 2008, Hukum Administrasi Negara, (Yogyakarta: Penerbit Universitas Atmajaya);

Undang-Undang Dasar Negara Republik Indonesia Tahun 1945;

Undang-Undang Nomor 1 Tahun 2004 tentang Perbendaharaan Negara;

Undang-Undang Nomor 15 Tahun 2004 tentang Pemeriksaan Pengelolaan dan Tanggung Jawab Keuangan Negara

Undang-Undang Nomor 17 Tahun 2003 tentang Keuangan Negara;

Undang-Undang Nomor 30 Tahun 2014 tentang Administrasi Pemerintahan.

Undang-Undang Nomor 31 Tahun 1999 juncto Undang-Undang Nomor 20 Tahun 2001 tentang Pemberantasan Tindak Pidana Korupsi;

Undang-Undang Nomor 5 Tahun 2014 tentang Aparatur Sipil Negara; 